diseases and in that of the so-called 'Social Problem Group'.

That characteristic of Sir Bernard Mallet which will have stamped itself most strongly on the minds of all his friends is the charm of his personality. He was a gentleman in the very highest sense of the word. He was always courteous and most helpful to his colleagues. Eugenics as an applied science demands not only theoretical knowledge but also the power to judge between conflicting human motives, needs and prejudices, with the result that the task of its leaders is at times one of extreme difficulty. The Eugenics Society was fortunate in securing the services of a president with such varied experiences, all of which helped him to fill with success the place which he only consented to occupy out of a sense of duty.

\section{Prof. K. K. GedroIz}

SoIn investigators all over the world will learn with deep regret of the death on October 5 of Prof. K. K. Gedroiz of the Dokuchaiev Soil Institute, Leningrad, and until lately president of the International Society of Soil Science. He was born in 1872 in Bessarabia, was educated in Kief and graduated in 1897 as a forest engineer at the School of Forestry in Leningrad. He then became assistant to Kossovitch at the Agro-chemical Laboratory of the Ministry of Agriculture. In 1915 he was appointed editor of the Russian Journal of Experimental Agriculture, and in 1919 was made professor of soils at the School of Forestry: later on, in 1922, he became lecturer in agricultural chemistry at Nossov, and after Glinka's death in 1928 he was elected a member of the Russian Academy of Science and director of the Dokuchaiev Soil Institute, where he was specially concerned with the laboratory investigations of the soil and also with the soils of the podsol zone.

Prof. Gedroiz for many years carried out important investigations on the process of absorption by soil, attributing it, as van Bemmelen had previously done, to complex reactive substances produced by weathering. Both in their composition and their interaction with dissolved salts these substances were generally so similar in type that he felt justified in speaking of a reactive 'soil complex' modelled on the same lines as a salt, in which the cations could be replaced by other bases or by hydrogen. In the 'complex' of a normal fertile soil the predominant cation is calcium; in other soils it might be sodium, magnesium or hydrogen. In developing these ideas he was able to give a rational explanation of many of the phenomena associated with acid and alkaline soils, and to clear up many obscurities in what had previously been a very difficult subject.

Prof. Gedroiz's work was long unknown to British and American investigators owing to its publication in Russian. A summary issued in an abstract journal attracted the attention of one or two
United States soil workers and they arranged for a translation of all of his papers into English. The volume was widely circulated among other soil investigators and at once ensured the recognition of the high merits of his work.

Gedroiz did much to make Russian soil science famous throughout the civilised world. His investigations into the soil complex and the phenomena of absorption fell easily into line with the studies on soil formation and classification initiated by Dokuchaiev and continued by a group of brilliant successors, Glinka, Neustruev and other workers still surviving: it gave a new and permanent direction to soil science. Gedroiz was of a modest and retiring disposition, rarely appearing at scientific gatherings: many soil investigators who visited Russia in 1930 were disappointed that they were unable to meet him and pay their respects to him. His work had sterling qualities which will ensure its place among the classics of modern science.

E. J. RussenL.

\section{Dr. Wiltitam Garnetr}

The death of Dr. William Garnett on November 1 , at the ripe age of eighty-one years, will cause a feeling of the very deepest regret to those of his contemporaries and coadjutors who knew and appreciated the man and his genius.

Dr. Garnett was born at Portsea on December 30, 1850, and was the son of William Garnett of that town. He received his early education at the City of London School, and continued it at the Royal School of Mines, having taken the first place among the Whitworth scholars in 1869. He afterwards proceeded to St. John's College, Cambridge, of which he was later elected a fellow, having been bracketed fifth wrangler in 1873 . He was the first demonstrator of physics in the Cavendish Laboratory under James Clerk Maxwell, whose biographer he became.

Fortunately for the cause of technical education, Dr. Garnett left Cambridge and associated himself with the developments of education which were then taking place. He was exceptionally well qualified to take up the position of a leader in the movement which was then developing throughout the length and breadth of the country for the advancement of what was termed 'technical education'. He held the position of professor of mathematics, physics and mechanies at University College, Nottingham, and later became principal and professor of mathematics in the Durham College of Science, Newcastle-upon-Tyne. Here he did splendid work. Realising that it was most important to associate the educational authorities with the development of technical education, he to some extent laid on one side his teaching duties at Newcastle-upon-Tyne with the view of obtaining an association between his college and the education authorities. He likewise found time during this period to write on behalf of technical education in the Technical World and other journals.

It was only natural, therefore, that Dr. Garnett

No. 3289 , Vol. 130] 
should be appointed secretary and educational adviser to the London County Council Technical Education Board in 1893. In this position, he probably achieved his most important work. He was largely responsible for the development of the London polytechnics and worked in harmony with both the City Parochial Charity Trustees and the great City companies. When the old Technical Education Committee was superseded by the London County Council Education Committee, Dr. Garnett was appointed educational adviser, and although this position relieved him of the responsibility of much educational routine, he exercised a great influence.

Dr. Garnett had a personality which was felt by all who were brought in contact with him. In his presence, none could fail to realise that they were dealing with a man of force of char. acter, ideals and originality. He had, moreover, the power of inspiring devotion in those with whom he was associated.

J. L. S. H.

WE regret to announce the following deaths:

Prof. U. S. Grant, professor and head of the Department of Geology and Geography at Northwestern University, Evanston, Illinois, who has done much work in economic and petrographic geology, on September 21, aged sixty-five years.

Prof. A. B. Hill, emeritus professor of hygiene and public health at the University of Birmingham, president of the Society of Medical Officers of Health in 1911-12 and of the Association of County Medical Officers in 1917-1924, a leading authority on national public health, on November 5, aged seventy-eight years.

\section{News and Views}

\section{Royal Society Medallists}

His MaJesty The King has approved of the following awards this year by the President and Council of the Royal Society in respect of the two Royal Medals : A Royal Medal to Prof. R. Robinson, for his distinguished work in organic chemistry ; A Royal Medal to Prof. E. Mellanby, for his distinguished work on dietary factors, especially in connexion with rickets. The following awards of medals have also been made by the President and Council : Copley Medal to Dr. G. E. Hale for his distinguished work on the magnetic field of the sun; Rumford Medal to Prof. F. Haber for his distinguished work in the application of thermodynamics to chemical reactions; Davy Medal to Prof. R. Willstätter for his distinguished researches in organic chemistry; Darwin Medal to Dr. C. E. Correns for his distinguished researches in genetics; Buchanan Medal to Prof. T. Madsen for his distinguished theoretical and practical work on immunity, especially in relation to diphtheria antitoxin; Hughes Medal to Dr. J. Chadwick for his distinguished researches on radioactivity.

\section{Barnaba Oriani, $1752-1832$}

THE centenary falls on November 12 of the death of the eminent Italian astronomer, Barnaba Oriani, who for many years was director of the Milan Observatory, and to whom Piazzi communicated his discovery of the minor planet Ceres. Piazzi first observed the planet on January 1, 1801, and a few weeks later he wrote to Oriani and Bode, the former of whom calculated its orbit. Oriani was born near Milan on July 17, 1752, and was educated by the Barnabites. He was made a priest at the age of twenty-three years and almost immediately entered the Observatory, which had not long since been founded at the College of Brera, Milan. He soon attained a recognised place among Italian astronomers and was among the first to publish tables of the planet Uranus, discovered by Herschel. In $\mathbf{1 7 8 6}$ he was sent to London to obtain instru- ments from Ramsden. At this time he became acquainted with Herschel, with whom he afterwards corresponded. With his colleagues, Francesco Reggio (1743-1804) and Angelo Cesaris (1750-1832), he carried out geodetical operations in northern Italy. $\mathrm{He}$ published various works on the motion of the planets. Although, during the greater part of Oriani's life Milan formed a part of the Austrian dominions, it was seized by the French in 1796, and in 1802 , the year in which Oriani was made director of the Observatory, it became the capital of the Cisalpine republic, with Napoleon as first president. On this occasion, it is said, that on Oriani's refusing to take the oath swearing hatred against monarchy, the wording of the oath was accordingly altered for him. Oriani's successors at Milan have included Carlini, Schiaparelli and Celoria.

\section{Atomic Projectiles}

Атомт projectiles and their applications formed the subject of the nineteenth Thomas Hawksley lecture delivered by Lord Rutherford on November 4 before the Institution of Mechanical Engineers. At present the maximum velocity that can be communicated to matter in bulk is not more than two miles a second. This is of the same order of magnitude as the average speed of the molecules of gases under ordinary conditions. But if we turn to individual charged atoms, methods have been developed which enable us to produce atomic projectiles moving with enormous speed. When the velocity becomes comparable with that of light, we have to take into account the change of mass of the particle with speed. As the velocity is generally produced by the acceleration of the particle in an electric field, it is convenient to speak of a thousand-volt particle, meaning thereby that the particle has the speed and energy equal to that gained in passing freely between two points differing in potential by a thousand volts. In the experiments of Cockcroft and Walton in the Cavendish Laboratory, Cambridge, a steady difference of potential up to 600,000 volts can be

No. 3289, Vol. 130] 